\title{
History of ethnocultural interaction in north and north-east Kazakhstan in the context of studying the kazakhstan model of national unity
}

\author{
DOI: 10.31551/2410-2725-2019-5-3-458-469
}

\section{Kozybaeva Mahabbat Malikovna}

scientific secretary of Ch.Ch. Valikhanov Institute of History and Ethnology, Republic of Kazakhstan, Almaty, Shevchenko, 28, DoctorPhD, koz.mahabbat_85@mail.ru

\section{Mamytova Saule Nasenovna}

professor of S. Toraighyrov Pavlodar State University, Republic of Kazakhstan, Pavlodar, Lomov, 64, Doctor of Historical Sciences, mamutova-pvl@mail.ru

Annotation. The scientific article is de voted to the study of the history of ethnocultural interaction, as well as the specifics of ethno-demographic processes in North and North-East Kazakhstan in the 18th - first half of the 20th centuries. in the context of studying the Kazakhstan model of national unity. In this article, the authors attempted to present the originality and evolution of ethnocultural interaction in a historical retrospective, the emphasis is on the interaction between the autochthonous Kazakh population and ethnic groups resettled here at different times. In particular, the authors analyze the processes of ethnocultural interaction of the displaced population with the indigenous Kazakh ethnic group, study the processes of ethno-demographic changes in the region in pre-revolutionary times, and then during the Soviet period during the Soviet power modernization, manifested in collectivization and industrialization, which influenced urbanization in the pre-war period, the consequences of forced deportation of peoples are investigated. The authors investigate the processes of interethnic interaction during the period of deportation and Stalin's repressions, when only Poles, Germans, Kurds, Armenians, Koreans, Assyrians, Kalmyks, Chechens, Crimean Tatars, Balkars, and others were expelled to Pavlodar Irtysh. a significant decrease in the proportion of Kazakhs in a regional society. The authors come to the conclusion that the content of ethnocultural interaction in the Soviet period was determined by the general ideology about the need to erase national faces, form a single community - the Soviet people. This greatly limited the ability to preserve ethnic identity. On the other hand, it was at this time that the foundations of the multi-ethnicity of the people of Kazakhstan were being laid, which became an active zone for the formation of interethnic tolerance, social harmony, characteristic of modern Kazakhstani society.

Keyword. Kazakhstan's model of national unity; ethnocultural interactions; North and North-East Kazakhstan; Cossack military colonization; peasant settlers; demographic processes; collectivization; industrialization; deportation; "special settlers".

\section{Солтүстік және Солтүстік-Шығыс Қазақстандағы өзара этномәдени қатынастар тарихы ұлттық бірліктің қазақстандық моделін зерттеу контексінде}

\section{Қозыбаева Махаббат Мәлікқызы}

Ш.Ш. Уәлиханов атындағы Тарих және этнология институтының ғалым хатшысы, Қазақстан Республикасы, Шевченко, 28, PhD докторы, koz.mahabbat_85@mail.ru

\section{Мамытова Сәуле Нәсенқызы,}

C. Торайғыров атындағы Павлодар мемлекеттік университетінің профессоры, Қазақстан Республикасы, Павлодар қ., Ломов, 64, тарих ғылымдарының докторы, mamutova-pvl@mail.ru

\begin{abstract}
Аңдатпа: Ғылыми мақала XVIII-XX ғасырдың алғашқы жартысындағы Солтүстік және СолтүстікШығыс Қазақстандағы өзара этномәдени қатынастар тарихын, этнодемографиялық үдерістердің ерекшелігін ұлттық бірліктің қазақстандық моделін зерттеу контексінде зерделеуге арналады. Мақалада авторлар өзара этномәдени қатынастар эволюциясы мен өзіндік бейнесін тарихи ретроспектива жағынан көрсетуге талпыныс жасайды, негізгі акцент автохтонды қазақ халқы мен әр түрлі кезеңдерде қоныс аударып келген этностармен өзара қатынасына жасалады. Соның ішінде авторлар қоныс аударған халықтар мен жергілікті қазақ ұлты арасындағы өзара этномәдени байланыстар үрдісіне талдау жасалып, аймақтағы төңкеріске дейінгі, содан кейін кеңестік кезеңдегі күштеп модернизациялау, ұжымдастыру мен индустриализациялау кезіндегі соғысқа дейінгі урбанизацияға ықпал еткен этнодемографиялық өзгерістер үдерісі, халықтарды күштеп депортациялаудың салдарлары қарастырылады. Авторлар депортация және сталиндік қуғын-сүргін кезіндегі, яғни Павлодардағы Ертіс бойына поляктар, немістер, күрдтер, армяндар, корейлер, ассииялықтар, қалмақтар, шешендер, қырым татарлары, балқарлар және т.б. жер аударылып жатқан кездегі этникааралық байланыстар үдерісін зерттейді. Өз кезегінде қоныс
\end{abstract}


аударушылар ағыны көрінісінде аймақтық социумда қазақтардың үлес салмағының біршама төмендеуі байқалады. Авторлар кеңес кезеңіндегі өзара этномәдени байланыстардың мазмұны ұлттық шекараларды өшіру қажеттігі туралы, кеңес халқы деп аталатын жалпы қауымды қалыптастыру туралы идеологиямен анықталды деген тұжырымға келеді. Бұл этникалық өзіндік ерекшелікті сақтау мүмкіндігін барынша шектеді. Бір жағынан, дәл осы уақытта полиэтникалық Қазақстан халқының негізі қалыптасып, қазіргі Қазақстан қоғамына тән этникааралық төзімділікті, қоғамдық келісімді қалыптастырудың белсенді аймағына айналады.

Түйін сөздер: Ұлттық бірліктің қазақстандық моделі; өзара этномәдени байланыстар; Солтүстік және Солүстік-Шығыс Қазақстан; әскери казактар отарлауы; шаруа-переселендер; демографиялық үдерістер; ұжымдастыру; индустриализациялау; депортация; «спецпереселендер».

\title{
История этнокультурного взаимодействия в Северном и Северо- Восточном Казахстане в контексте изучения казахстанской модели национального единства \\ Козыбаева Махаббат Маликовна
}

ученый секретарь Института истории и этнологии им. Ч.Ч. Валиханова, Республика Казахстан, г. Алматы, Шевченко, 28, доктор PhD, koz.mahabbat_85@mail.ru

\section{Мамытова Сауле Насеновна,}

профрессор Павлодарского государственного университета им. С. Торайгырова, Республика Казахстан, г.Павлодар, Ломова, 64, доктор исторических наук, mamutova-pvl@mail.ru

Аннотация. Научная статья посвящена изучению истории этнокультурного взаимодействия, а также специфики этнодемографических процессов в Северном и Северо-Восточном Казахстане в XVIII - первой половине XX вв. в контексте изучения казахстанской модели национального единства. В данной статье авторами предпринята попытка представить своеобразие и эволюцию этнокультурного взаимодействия в исторической ретроспективе, акцент сделан на взаимодействие между автохтонным казахским населением и переселившимися сюда в разное время этносами. В частности, авторами анализируются процессы этнокультурного взаимодействия переселенческого населения с коренным казахским этносом, изучаются процессы этнодемографических изменений в регионе в дореволюционное время, а затем и в советский период во время силовой советской модернизации, проявившейся в коллективизации и индустриализации, повлиявших на урбанизацию в довоенный период, исследуются последствия насильственной депортации народов. Авторы исследуют процессы межэтнического взаимодействия в период депортации и сталинских репрессий, когда только в Павлодарское Прииртышье были высланы поляки, немцы, курды, армяне, корейцы, ассирийцы, калмыки, чечены, крымские татары, балкарцы и др. В свою очередь на фоне притока переселенцев происходит значительное снижение удельного веса казахов в региональном социуме. Авторы приходят к выводу, что содержание этнокультурного взаимодействия в советский период определялось общей идеологией о необходимости стирания национальных граней, формирования единой общности - советский народ. Это крайне ограничивало возможности сохранения этнической идентичности. С другой стороны, именно в это время закладываются основы полиэтничности народа Казахстана, который становится активной зоной формирования межэтнической толерантности, общественного согласия, характерной для современного казахстанского общества.

Ключевые слова. Казахстанская модель национального единства; этнокультурные взаимодействия; Северный и Северо-Восточный Казахстан; военно-казачья колонизация; крестьяне-переселенцы; демографические процессы; коллективизация; индустриализация; депортация; «спецпереселенцы».

\section{УДК/UDC 325}

\section{История этнокультурного взаимодействия в Северном и Северо- Восточном Казахстане в контексте изучения казахстанской модели национального единства}

\author{
М.М. Козыбаева, С.Н. Мамытова
}

Введение. В эпоху мировых катаклизмов и конфликтов, в том числе на этнической почве именно Казахстан является примером стабильности в сфере 
межэтнических и межрелигиозных отношений. В этом огромная заслуга уникального института - Ассамблеи народа Казахстана, которая осущестляет большую работу по проведению многовекторной этнической политики в стране. В республике при численности населения более 18 миллионов человек в согласии проживают представители более 130 этнических групп и 17 конфессий. На сегодня казахстанская модель межэтнического мира и согласия стала визитной карточкой страны на авторитетных диалоговых площадках мира. Между тем, актуальным вопросом остается исследование истории формирования полиэтнического населения в Казахстане, а также специфики этнокультурного взаимодействия.

Этнокультурное взаимодействие является неотъемлемой частью исторического развития практически всех народов мира. Оно определяет его темпы и качество развития. Из истории известно немало примеров, когда народы пытались жить в изоляции, что лишало их возможности дальнейшего развития и, в конце концов, приводило к отставанию от других народов и стран. Казахстан всегда развивался по пути открытости к межкультурному диалогу. За несколько веков сосуществования различных этносов накоплен богатейший опыт межэтнического взаимодействия.

На современном этапе в Республике Казахстан сохранение этнокультурного многообразия, влияние внешних процессов, связанных с глобализацией, а также перспективы дальнейшего развития диктуют целесообразность учета и использования этого опыта. Этнокультурное взаимодействие, без сомнения, выступает ценным историческим наследием. Его знание позволяет гражданам опираться на традиции толерантности и взаимовыгодного сотрудничества, сложившиеся на протяжении многих веков взаимодействия этносов, населяющих Казахстан. Вместе с тем, обращение к историческому опыту межэтнического взаимодействия, на наш взгляд, может помочь в выявлении фракторов взаимовыгодной интеграции - одной из важных базисных условий для этнополитической стабильности и развития межкультурного диалога.

Актуальность исследования связана также с региональным подходом этнической истории. Северный и Северо-Восточный Казахстан являлся одним из ведущих аграрно-сырьевых регионов как республиканского, так и общесоюзного значения. Достаточно высокие темпы колонизации, переселенческого движения в дореволюционный период, а также урбанизации в период гражданской войны, голода начала 1920-х гг., 1932-1933 гг., депортации, а также в период массовых политических репрессий 1937-1938 гг., оказали огромное влияние на динамику и этнический состав населения страны. Именно в этот период формируется сложная социально-демографическая структура населения, а Казахстан становится полиэтническим и поликультурным регионом.

Материалы и методы. Источниковой базой исследования выступили материалы переписей населения (например, Всесоюзные переписи 1920, 1923, 1926, 1937, 1939 гг. и т.д.), а также материалы Центрального государственного архива Республики Казахстан (ЦГА РК), Северо-Казахстанского государственного архива (СКГА), Государственного архива Павлодарской области (ГАПО) и Т.д. Методологической основой исследования являлся принцип историзма, поскольку выбранные нами в качестве объекта исследования этнодемографические процессы в Северном и Северо-Восточном Казахстане исследуются в своем эволюционном развитии и претерпевают изменения в обозначенный период. Системный подход позволяет представить 
этнокультурные взаимодействия, обладающие многообразными внутренними элементами, связями и процессами, как составную часть более широкой системы взаимоотношений. Многомерность и сложность объекта исследования определяют в качестве одного из основных также междисциплинарный подход. Для оценки уровня этнодемографических и этнокультурных процессов необходима сумма отдельных исследований социологического, демографрического, экономического и культурологического характера. В исследовании использован синтез макро- и микроисторических подходов. При написании научной статьи применялись также общенаучные методы: анализ, синтез, статистический метод. Теоретическую основу исследования составили работы представителей отечественной исторической мысли, внесших вклад в изучение истории формирования полиэтнического населения Казахстана.

Обсуждения. В результате исследования этно-демографических процессов и проблемы межэтнического взаимодействия в Казахстане сформирована крупная историографическая база. Среди ведущих отечественных исследователей - такие исследователи как Абусеитова М.К. (Абусеитова, 1998), Кабульдинов 3.Е. (Кабульдинов, 2012), Артыкбаев Ж.О. (Артыкбаев, 2005), Султангалиева Г.С. (Султангалиева, 2005), Каженова Г.Т. (Каженова, 2007) и другие. Большую ценность в изучении динамики этнической картины региона представляют работы исследователей Н.В. Алексеенко (Алексеенко, 1981), И.Д. Никифорова (Никифоров, 1988), Асылбекова М.Х., Галиева А.Б. (Асылбеков, Галиев, 1991), Кудайбергеновой А.И. (Құдайбергенова, 2011), Саркеновой К.А. (Саркенова, 2011) и других. В них анализируется исторический процесс формирования этнической структуры населения Казахстана, в том числе в североказахстанском регионе в ходе миграций. С другой стороны, проблема межэтнических взаимоотношений в регионе остается малоизученной, а сложность диалектики таких отношений обусловила широкую научную дискуссию. Особенно сейчас, когда происходят сложные миграционные процессы, фрактор многообразия и различия культур интерпретируют в качестве источника реальных и потенциальных конфлликтов и противоречий. В этой связи на многих научных фрорумах звучит справедливая мысль о необходимости теоретического и методологического поиска парадигмы осмысления места и роли этнокультурного взаимодействия в социально-экономическом и общественно-политическом развитии страны.

Результаты. Территория Северного и Северо-Восточного Казахстана, занимающего пограничное положение между степным краем и Западной Сибирью, издавна стала зоной активных контактов многих этносов. Особенно тесное переплетение получили исторические судьбы тюркских и славянских этносов. Это взаимодействие имело полуторатысячную историю и разную целевую направленность. В отличие от западных миграций тюркских народов, славянское распространение на восток, активно начавшееся с начала XVIII века, имело иную политическую и хозяйственную подоплеку. Оно было тесно связано с имперскими устремлениями северного соседа России, которая начала военно-казачью колонизацию региона. Здесь сформировалась особая территория, в границах которой осуществлялось культурное и экономическое взаимодействие казаков и казахов. В основном, оно носило неравноправный характер. Казаки, выступая оплотом колонизации, вероломно захватывали скот и иное имущество казахов, совершая регулярные рейды в степи. Например, за Сибирским казачьим войском было закреплено более 5 миллионов лучших земель, изъятых у местного населения. В дальнейшем именно эти земли стали местами тесного контакта казаков и казахов. Последние брали в аренду земли 
казаков или нанимались к ним в качестве батраков. Это была наиболее распространенная практика межэтнического взаимодействия в регионе.

Кроме джатаков (обедневших, оставшихся без скота, казахов) в систему производственных взаимоотношений на землях казачества активно вступали и собственно кочевники-скотоводы. Арендуя земельные угодья у казачества, они круглогодично, а также компактно проживали, для примера, в станицах Павлодарского уезда, численно превосходя казаков этих станиц. Например, в станице Урлютюпской - на 3022 казака приходилось 4365 казаха, в Песчановской - 3177 и 5057, соответственно ${ }^{1}$. Данная демографическая ситуация, а также политические реалии XVIII - начала XIX века определили тот факт, что заимствование в процессе взаимодействия было более характерно для казачества, чем для местного казахского населения. Адаптируясь к новым природно-климатическим условиям, казаки заимствовали хозяйственный опыт кочевников. Они занимались преимущественно скотоводством, как и казахи, практиковали табунное содержание скота на подножном корму.

Межэтническое взаимодействие в экономической сфере не могло не оказать влияние и на культурно-бытовую деятельность. Об этом свидетельствуют многочисленные примеры заимствования элементов одежды, питания, жилья, домашней утвари и т.п. Известный тюрколог В.В. Радлов писал о широкой популярности казахского халата среди казаков, которые носили его не только дома, но могли явиться в нем и на службу (Радлов, 1989: 83). Для пошива верхней мужской одежды казаки использовали казахскую армячину из верблюжьей шерсти. Н.М. Ядринцев, описывая жизнь инородцев, приводил различные факты их взаимоотношений с русскими казаками: «казаки заимствуют у киргизов одежду, обычаи, язык. Нравы эти проникают даже в среду офицерского сословия. Иногда офицеры являются в города совершенно окиргизившиеся» ${ }^{2}$.

Дореволюционные исследователи также отмечали влияние сосуществования этносов на антропологические изменения, формирование во внешнем облике казаков-старожилов неславянских черт: «уклонение от русского типа к монгольскому». Ф. Усов объяснял это следующим образом: «...на пограничных сибирских линиях долгое время было чрезвычайно мало русских женщин, и казаки женились на инородках» ${ }^{3}$. Кроме того, среди казаков немало было людей нерусской этнической принадлежности: и казахи, и калмыки, и башкиры, и мордва. По словам политического ссыльного, исследователя истории Степного края Н. Коншина, на дворе казака можно было часто встретить юрту, в которой он проживал со своим семейством в летнее время ${ }^{4}$. Практически все казаки свободно владели казахским языком. Г.Н. Потанин в связи с этим писал, что казаки предпочитали казахский язык родному языку из-за его «легкости». Так же он писал: «для многих это колыбельный язык, потому что няньками и стряпками здесь бывают киргизки, ...между здешними казаками встречаются лица, которые обстоятельнее рассказывают дело на киргизском, чем на русском ...в своих рапортах сбиваются с русского языка и оканчивают доклад на киргизском» ${ }^{5}$.

\footnotetext{
${ }^{1}$ Центральный государственный архив Республики Казахстан (далее ЦГА РК). Ф.15. Оп.1. Д.2217. Л. 6-7.

${ }^{2}$ Ядринцев Н.М. Раскольничьи общины на границе Китая // Сибирский сборник. 1897. Кн. 1. С.24.

3 Усов Ф. Статистическое описание Сибирского казачьего войска. СПб.: Издание главного управления иррегулярных войск, 1879. С.68.

Коншин Н. Очерки экономического быта киргиз Семипалатинской области // Памятная книжка Семипалатинской области на 1901 г. Семипалатинск, 1901. С.179.

${ }^{5}$ Потанин Г. Заметки о сибирском казачьем войске // Военный сборник. Т. ХІХ. СПб., 1861. С. 6-7.
} 
Казаки в питании, под влиянием окружающих их казахов, отдавали предпочтение мясной пище, особенно баранине. В свою очередь, у казахов под влиянием казаков начала формироваться иная культура потребления пищи и жилья - стали есть больше хлеба, строить стационарные жилища и т.д. Тем не менее, нельзя говорить о глубокой трансформации хозяйственной деятельности и традиционного этнического самосознания, как казачества, так и казахов. У казахов пашня не вытеснила пастбище. Она совместилась с ним, породив новые типы хозяйственного симбиоза. Каждый из контактирующих этносов переживая мощные процессы аккультурации, сохранял собственную этничность. Казахи оказывали сильнейшее сопротивление колониальной политике ассимиляции, русификации. В 30-x годах XIX века казахи родов козган, айдабол, каржас и др. приняли деятельное участие в национальноосвободительном движении Кенесары Касымова (Инсебаев, 2000: 177).

Следует признать, что длительность заселения края переселенцами создает большую сложность в изучении процессов межэтнического взаимодействия. Каждый этап развития региона накладывал свой отпечаток на процесс взаимодействия этносов.

Процессы межкультурной коммуникации получили более интенсивное развитие с крестьянской, а затем правительственной колонизации края - это со второй половины XIX - начала XX вв. В результате масштабного изъятия наиболее плодородных земель у кочевников началась трансформация их традиционного хозяйства в сторону оседлости. Они были вынуждены адаптироваться и изменять привычные формы хозяйства и жизни. Однако это еще не носило больших масштабов. Среди казахов Павлодарского Прииртышья, которые составляли в начале XX века 90,2\% населения, абсолютное большинство занималось кочевым скотоводством.

Наиболее активно процесс взаимодействия этносов происходил при усвоении близких тому или иному типу мышления ценностей. Развитие рыночных отношений сформировало комплекс общих ценностей. Казахи и переселенцы вели оживленную торговлю на ярмарках, городах, торговых домах. В ходе коммерческих операций они знакомились с языком друг друга, традициями. Деловые контакты перерастали в содружество, ярким примером которого является «тамырство». Оно означало такие отношения между казахами и русскими, или представителями других национальностей, которые строились на взаимопонимании потребностей друг друга.

Наиболее близкими для казахов были татары и башкиры, с которыми было много общих этнокультурных черт (в языке, традициях и обычаях, единая конфессиональная принадлежность). Этот факт использовался Россией, которая со второй половины XVIII века стала осуществлять политику заселения татар в степном крае. Таким образом, она стремилась обеспечить лояльность тюрко-мусульманских народов по отношению к имперской власти. Однако практика взаимодействия не дала нужного для империи эффекта. Наоборот, под влиянием татарской культуры произошло еще большее сближение с восточными ценностями, утвердилось духовно-просветительское направление в казахской культуре.

Сохраняя свои традиции, казахи в обустройстве оседлой жизни определенные элементы восприняли от переселенцев. Общаясь с ними, расширился их круг знаний и навыков по хозяйству, быту и культуре крестьян. В свою очередь казахи передавали свой опыт скотоводческого хозяйства, без которого здесь вообще невозможно было прожить. Продолжительный период их совместного проживания в новой природно-ландшафтной зоне 
сопровождался определением сферы взаимных интересов и развитием на их основе межэтнических контактов.

Советский период характеризуется повышением степени полиэтничности общества. В годы силовой модернизации происходили крупные изменения в социально-демографической структуре населения Северного Казахстана, начало которым положили массовые крестьянские миграции из центральных районов России в конце XIX - начале XX вв. В первые годы после революции организованного массового переселения в Казахстан не проводилось. Однако, стихийная миграция населения в Казахстан в связи с разрухой и, в особенности с голодом 1921 г., продолжалась.

Население Северного Казахстана в 1920-1930-е гг. также формировалось, в основном, путем трудовых миграций, а также за счет так называемых спецпереселенцев, и было довольно разнородно в этническом плане. Основной характеристикой социально-демографических процессов в 1920-1930-е гг. было массовое переселенческое движение в Северный Казахстан из России, Украины, Белоруссии и других республик (Асылбеков, Галиев, 1991: 65).

В связи с данными процессами в Северном Казахстане складывается полиэтническая структура населения. Так, исследователь Саркенова К.А. обращает внимание на тот факт, что в период 1923-1926 гг. 71,8\% городского населения Каз АССР было представлено европейскими национальностями: украинцами, немцами, белорусами, также татарами. Доля казахов в национальном составе городского населения составляла только 13,9\% (Саркенова, 2010: 58).

Похожая ситуация имела место и в изучаемом регионе. Из данных переписи 1923 г. следует, что подавляющая часть городов Северного Казахстана была населена русским населением: в Павлодаре русское население составило 61,8\% от всего населения, в Петропавловске - 69,6\%, в Костанае - 73,7\%. Второй по количественному составу являлась татарская диаспора, составлявшая $14 \%$ от всего городского населения. Казахское же население в городах было представлено незначительно, всего лишь 8,8\% ${ }^{6}$. Статистические данные показывают, что коренное население пополняло город не слишком значительно, вследствие специфики хозяйственного уклада жизни, и только набирающего обороты процесса насильственного оседания. В целом, за три межпереписных года коренное население в городах республики увеличилось с 7,2 до 8,8\% ${ }^{7}$. По данным переписи 1920 г. казахское население в городах Кустанайской губернии составляло всего лишь 0,2\% (55 чел.), по данным 1923 г. - 1,7\% (356 чел.). В Акмолинской губернии в городах в 1920 г. казахское население составило 7,3\% (3994 чел.), а в 1923 г. - 9,9\% (6836 чел.). На данном этапе казахское население пополняло административный аппарат только «необходимым» числом людей, и редко решало действительно важные вопросы в самоуправлении. Коренное население, проживая в сельской местности, организовывалось лишь на местном уровне. У власти на эту проблему была своя точка зрения: «Степь живет своей особенной жизнью и патриархальный уклад жизни киргиза кочевника, его оторванность от остального мира и поголовная безграмотность создают то средостение, которое стоит пока непреодолимым препятствием к широкому проникновению

\footnotetext{
${ }^{6}$ Всесоюзная городская перепись 1923 года: (В 2-х вып.). - М., 1923. - 2 т. (Труды Центрального Статистического управления; Т. 27).

${ }^{7}$ Харлампович К. Национальный состав городов КССР по переписи 1923 года // Статистический вестник. Оренбург, 1925. № 5. С. 55-67.
} 
в киргизские степи тех идей, которыми живёт пролетариат городов» ${ }^{8}$. Таким образом, основная часть городского населения была представлена в основном европейским населением, продолжающим заселять, как и в царский колониальный период, север Казахстана.

К середине 1920-х гг. В североказахстанском регионе заметно снизился процент казахского населения, однако выросла доля других этносов - в первую очередь русского и украинского населения, что является следствием массового переселения в Северный Казахстан из районов центральной России и Поволжья. Во всем регионе казахское население составляло 38,76\% от общего числа населения, то есть 718647 человек, когда как русские составляли 33,78\%, украинцы - 23,17\%, немцы - 1,76\%, татары - 1,34\%, мордва - 0,54, белорусы - 0,18, другие национальности $-0,47 \%{ }^{9}$.

Статистические данные свидетельствуют малочисленность казахов в числе городского населения Северного Казахстана. Наиболее высокая численность казахов зафиксирована в г. Акмолинске - 4403 человека, наименьший показатель в г. Костанай - 412 человек. Подобная статистика может утверждать, по-прежнему казахи предпочитали проживать в сельской местности, а руководство не торопило привлекать их в качестве управленцев. Дело в том, что города, оставаясь центрами управления края, содержали исполнительные органы, которые в подавляющем большинстве были представлены русскоязычной массой для быстрой связи с центром. В связи с этим, вопрос об участии коренного населения в управлении североказахстанским регионом и использовании в делопроизводстве казахского языка находился на уровне вынужденного обсуждения ${ }^{10}$.

В материалах Всероссийской переписи 1926 г. представлены статистические данные о национальном составе городов Акмолинск, Петропавловск, Кокчетав, Атбасар Акмолинской губернии, 4 городов (в том числе г. Павлодар) Семипалатинской губернии, а также г. Кустаная Кустанайского округа. Даже в разрезе городов севера и востока Казахстана, ситуация остается неизменной: преобладание русского населения было существенным и составляло более $63 \%$. Тогда как казахи, в том числе за счет других городов Семипалатинской губернии (куда входил и г. Павлодар), достигли всего около 13\% от численности всего городского населения. На третьем месте стояли татары почти $12 \%$, начавшие заселять край еще в конце XIX в. в ходе крестьянской и миссионерской миграции. Вследствие преобладания русскоязычного населения в городах Северного Казахстана начинается постепенный процесс языковой ассимиляции. Русский язык постепенно становится фрактором социальной и политической успешности индивида, вне зависимости от его национальной принадлежности.

Социально-демографическое развитие Северного Казахстана в период усиления тоталитаризма в 1928-1937 гг. представляет собой весьма сложный и противоречивый процесс, имевший в качестве последствий не только коренные изменении в социально-экономическом и культурном развитии, но и усилением миграционных и демографических процессов в результате перехода к новым фрормам и методам управления. Сложные продовольственные проблемы, вылившиеся в голод начала 1930 гг., а также

8 Отчет Бюро Кустанайского Губернского Комитета РКП (б) за ноябрь месяц 1923 года // Известия Кустанайского губернского исполнительного комитета РКП. 1923. № 20. С. 44-53.

${ }_{9}$ Всесоюзная перепись населения 1926 г. - Алма-Ата: Б.и., 1928. 164 с. С.38.

${ }^{10}$ Всесоюзная перепись населения 1926 года. Народность. Родной язык. Возраст. Грамотность. М.: Издание ЦСУ Союза ССР, 1928. Том VIII: Казахская АССР. Киргизская АССР. С.134-147. 
многочисленные миграции населения (добровольные и вынужденные) в регионе не могли не сказаться на демографической ситуации в Северном Казахстане.

В конце 1920 - начале 1930-х гг. в Казахстан начинают прибывать раскулаченные крестьяне-переселенцы из России, Украины и других республик так называемые «спецпоселенцы» (1930 г.) или «трудпоселенцы» (с 1933 г.) (Из истории, 2012: 33). В данной ситуации города становились временными пунктами приема высланного населения. Так, в протоколе заседания тройки при Павлодарском окротделе ОГПУ о мероприятиях по ликвидации кулачества как класса, в том числа среди немецкого населения от 27-28 января 1930 г. было решено «высылку кулаков и баев из г. Павлодара производить партиями в 100-300 человек, учитывая недостаточность помещений, могущих быть использованными для содержания их под стражей» ${ }^{11}$.

Кроме механического движения населения, в данный период наблюдалось самое значительное сокращение численности населения, вызванное страшным голодом 1930-х гг. При этом сверхвысокая смертность свирепствовала в Казахстане с 1928 по 1934 гг. включительно. Известно, что в гг. Акмолинске, Кустанае, Петропавловске смертность среди населения более чем в два раза превышала рождаемость. Естественный прирост за первые пять месяцев 1933 г. был отрицательным по всем городам Казахстана. Однако в большей степени голод затронул в первую очередь сельское население. Так, жертвами голода стали в этот период 1 млн. 750 тыс. чел. или 42\% всей численности казахского населения В республике, произошло снижение численности украинцев - с 859,4 тыс. до 658 тыс., узбеков - с 228,2 тыс. до 103,6 тыс. и т.д. В Северном Казахстане было потеряно 400,9 тыс. чел. или $51,4 \%$, то есть более половины представителей казахского населения. В этой ситуации города становились приемным пунктом сельских беженцев.

Переселенцы влияли и на этнический состав городов. Так, например, по национальному составу население Петропавловска в 1932 г. было представлено следующим образом: русские - 42878 (70,3\%), татары - 8103 (13,3\%), казахи - 6397 (10,5\%), украинцы - 1421 (2,3\%), немцы - 651 (1,1\%), евреи - 420 $(0,7 \%)$, поляки - $258(0,4 \%)$, грузины - 12 чел., прочие - $820(1,4 \%)^{12}$. Таким образом, русскоязычное население продолжало преобладать в городской среде в течение всего периода.

Аграрная катастрофа повлекла за собой ускоренные темпы урбанизации во второй половине 1930-х гг. В национальном составе городов Северного Казахстана по-прежнему преобладало русское население, составлявшее более 63\% всего городского населения региона. Практически на этом же уровне осталась доля коренного населения: казахи составляли 16,9. Значительную долю населения представляли украинцы - 8,9\%, а также татары - 6,2\%. Наибольший удельный вес казахского населения наблюдался лишь малых городах: в г. Атбасаре - 25,9\% (1568 из 6035 человек населения), а также во вновь образованных производственных городах, бывших до недавнего времени рабочими поселками: г. Степняк - 32,22\% (7373 из 22882 человек) и г. Джетыгара - 30,79\% (4725 из 15345 человек). Это говорит о постепенном увеличении среди рабочего населения доли казахского

\footnotetext{
${ }^{11}$ Государственный архив Павлодарской области (далее ГАПО). Ф. 8-П. Оп.1. Д. 293. Л.3.

${ }^{12}$ Северо-Казахстанский государственный архив (далее СКГА). Ф. 922. Оп. 1. Д.1. Л.41
} 
населения вследствие форсированной политики коллективизации и ускоренной индустриализации ${ }^{13}$.

Необходимо помнить, что со второй половины 1930-х гг. продолжается насильственная депортация населения в различные регионы страны, в том числе в Северный Казахстан. Только в Павлодарское Прииртышье были высланы поляки, немцы, курды, армяне, корейцы, ассирийцы, калмыки, чеченцы, крымские татары, балкарцы и другие. Политические процессы второй половины 1930-х гг. повлияли на демографические процессы в регионе, в связи с движением лиц различной квалификации и большой текучести партийных кадровых работников. В этот же период начал раскручиваться маховик репрессий, достигший своего пика в 1937 г. Так, в Павлодаре уже к 1935 г. из городской партийной организации было изгнано и репрессировано около 30\% коммунистов, были заменены почти все первые и вторые секретари райкомов партии. Не обошли репрессии учителей, врачей, руководителей учебных заведений, служителей религиозного культа.

Северный регион Казахстана стал местом политической ссылки для репрессированных и членов их семей (ЧСИР). Сюда было сослано немало ленинградцев после убийства С.М. Кирова в декабре 1934 г. «Просим наше правительство беспощадно расправиться с убийцами Кирова, - требовали горожане. - Смерть Кирова дорого обойдётся врагам». И правительство расправлялось. Например, в г. Акмолинске располагалась печально известный АЛЖИР - Акмолинский лагерь жен-изменников Родины. В г. Павлодар ссылались и те, кто отбывал сроки в лагерях ГУЛАГа: командир крейсера «Аврора» Валентин Евгеньевич Эмме, (похоронен на павлодарском кладбище в 1970 г.); здесь же похоронены Юлий Готфридович Венске, выпускник Гамбургского университета, инженер-кораблестроитель, стоявший у истоков советского торгового фрлота; известный ученый-путешественник Евгений Сергеевич Гернет. Долгие годы здесь жила семья автора грозного оружия «Катюша» Георгия Эриховича Лангемака. Всего в Павлодарском Прииртышье было арестовано свыше 4500 человек, расстреляно более 800 репрессированных, из них 554 человека в 1937 г.

Статистические данные свидетельствуют о том, что во всех городах около 5\% населения составлял так называемый «спецконтингент», подсчитанный специальными органами внутренних дел, и добавленный уже после опубликования основных результатов переписи 1939 г. Интересно отметить, что контингент спецпереселенцев был представлен в основном мужским населением, который превосходил в количественном плане женское население почти в 4 раза (9633 мужчин против 2181 женщин). По нашему мнению, такая специфика была обусловлена тем, что спецпереселенцы в основном работали на добыче полезных ископаемых, то есть были заняты тяжелыми видами производства.

Заключение. Анализ этно-демографических процессов в Северном и Северо-Восточном Казахстане показал, что в годы индустриализации, Великой Отечественной войны, депортации народов, а позже и освоения целины сложилась противоречивая этническая ситуация. С одной стороны, произошел приток новых мигрантов на территорию региона, что открывало возможности для широкой социальной практики межэтнического взаимодействия. С другой стороны, на фоне притока переселенцев происходит значительное снижение

${ }^{13}$ Всесоюзная перепись населения 1939 г. Краткие итоги. - М., 1991. - 167 с.; РГАЭ, Ф.1562, Оп.7. ДД. 256427, табл. 26. Национальный состав населения районов, районных центров, городов и крупных сельских населенных пунктов. 
удельного веса казахов в региональном социуме. По данным 1959 г. в регионе осталось только 25,6\% казахов. Социалистическая модернизация оказалась, в конечном счете, разрушительной, как для коренного этноса, так и тех, кто не по своей воле оказался на этой земле. Речь идет о народах, подвергшихся насильственной депортации. Страшной трагедией для казахского народа обернулась непродуманная политика насильственной седентаризации и коллективизации. Массовые политические репрессии породили психологическую напряженность. Содержание этнокультурного взаимодействия определялось коммунистической идеологией о необходимости стирания национальных граней, формирования единой общности - советский народ. Это, безусловно, крайне ограничивало возможности сохранения этнической идентичности. В частности, одной из важных проблем, получившей продолжение и в современном обществе, является потеря родного языка у представителей многих этносов. С другой стороны, именно в это время Северный Казахстан закрепил за собой статус полиэтничного региона, а его города выступили инициаторами взаимодействия этносов, что заложило фундамент для формирования толерантности, характерной для современного казахстанского общества.

\section{Әдебиеттер тізімі / Список литературы}

1. Абусеитова, 1998 - Абусеитова М.X. Казахстан и Центральная Азия в XVI-XVIII вв.: история, политика, дипломатия. Алматы: Дайк-Пресс, 1998. 268 с.

2. Алексеенко, 1981 - Алексеенко Н.В. Население дореволюционного Казахстана (численность, размещение, состав: 1870-1914 гг.) Алма-Ата: Наука, 1981. 255 с.

3. Артыкбаев, 2005 - Артыкбаев Ж.О. Кочевники Евразии (в калейдоскопе веков и тысячелетий). СПб.: Мажор, 2005. 320 с.

4. Асылбеков, Галиев, 1991 - Асылбеков М.Х., Галиев А.Б. Социально-демографические процессы в Казахстане (1917-1980 гг.) Алматы: Ғылым, 1991. 288 с.

5. Из истории депортаций Казахстан. 1930-1935 гг. Сборник документов. Алматы: LEM, 2012. 772 c.

6. Инсебаев, 2000 - Инсебаев Т.А. Очерки истории Павлодарского Прииртышья. Павлодар: Эко, 2000. $240 \mathrm{c}$.

7. Кабульдинов, 2012 - Кабульдинов 3.Е. (отв. ред.). Проблемы этнической истории тюркского населения Западной Сибири. Астана: Мастер ПО, 2012. 308 с.

8. Каженова, 2007 - Каженова Г.Т. Этнокультурные особенности сибирского казачества в контексте взаимодействия и взаимовлияния с казахским населением степного края (XIX в.) // Вестник Карагандинского университета. Серия История, философрия, право. 2007. № 3.С.23-30.

9. Құдайбергенова , 2011 - Құдайбергенова А.И. Қазақстандағы көші-қон үрдістерінің тарихи демографиялық қыры (1917-1991). Алматы: Елтаным, 2011. 416 б.

10. Никифоров, 1988 - Никифроров И.Д. Городское население Казахстана (1917-1939 гг.) АлмаАта: Наука, 1988. 24 с.

11. Радлов, 1989 - Радлов В.В. Из Сибири: страницы из дневника. М.: Наука, 1989. 749 с.

12. Саркенова, 2011а - Саркенова К.А. 1920-1930 жылдардағы Қазақстан халқы. Алматы: Қазақ университеті, 2011. 220 б.

13. Султангалиева, 2000 a - Султангалиева Г. «Татарская диаспора» в конфессиональных связях казахской степи (XVIII-XIX вв.) // Вестник Евразии. 2000. № 4. С.20-37.

\section{References}

Abuseitova, 1998 - Abuseitova M.KH. Kazakhstan i Tsentral'naya Aziya v XVI-XVIII vv.: istoriya, politika, diplomatiya. [Kazakhstan and Central Asia in the 16th-18th centuries: history, politics, diplomacy] - Almaty, 1998. Dayk-Press.268 s. [In Rus.]

Alekseyenko, 1981 - Alekseyenko N.V. Naseleniye dorevolyutsionnogo Kazakhstana (chislen-nost', razmeshcheniye, sostav: 1870-1914 gg.) [The population of pre-revolutionary Kazakhstan (number, location, composition: 1870-1914)]. Alma-Ata: Nauka, 1981. 255 s. [In Rus.] 
Artykbayev, 2005 - Artykbayev Zh.O. Kochevniki Yevrazii (v kaleydoskope vekov i tysyacheletiy). [Nomads of Eurasia (in a kaleidoscope of centuries and millennia]. SPb: Mazhor, 2005. 320 s. [In Rus.]

Asylbekov, Galiyev, 1991 - Asylbekov M.Kh., Galiyev A.B. Sotsial'no-demograficheskiye protsessy v Kazakhstane (1917-1980 gg.) [Social and demographic processes in Kazakhstan (1917-1980)]. Almaty: Gylym, 1991. 288 s. [In Rus.]

Iz istorii deportatsiy Kazakhstan. 1930-1935 gg. [From the history of deportations Kazakhstan. 19301935] Sbornik dokumentov. Almaty: LEM, 2012. 772 s. [In Rus.]

Insebayev. 2000 - Insebayev T.A. Ocherki istorii Pavlodarskogo Priirtysh'ya. [Essays on the history of Pavlodar Priirtysh'ye]. Pavlodar, 2000. 240 s. [In Rus.]

Kabul'dinov, 2012 - Kabul'dinov Z.Y. (otv. red.). Problemy etnicheskoy istorii tyurkskogo naseleniya Zapadnoy Sibiri. [Problems of the ethnic history of the Turkic population of Western Siberia]. Astana: Izd-vo "Master PO", 2012. - 308 s. [In Rus.].

Kazhenova, 2007 - Kazhenova G.T. Etnokul'turnyye osobennosti sibirskogo kazachestva v kontekste vzaimodeystviya i vzaimovliyaniya $s$ kazakhskim naseleniyem stepnogo kraya (XIX v.) [Ethnocultural features of the Siberian Cossacks in the context of interaction and mutual influence with the Kazakh population of the steppe region (XIX century)] // Vestnik Karagandinskogo universiteta. Seriya Istoriya, filosofiya, pravo. 2007. № 3. S.23-30. [In Rus.]

Qudaybergenova, 2011 - Qudaybergenova A.I. Qazaqstandaġy keshíkon urdísteríní tarikhi demografiyalyk, kyry (1917-1991) [Historical and demographic aspects of migration processes in Kazakhstan (1917-1991)]. Almaty: Yeltanym, 2011. 416 b. [In Kaz]

Nikiforov, 1988 - Nikiforov I.D. Gorodskoye naseleniye Kazakhstana (1917-1939 gg.) - Alma-Ata: Nauka, 1988. - 24 s. (Nikiforov I.D. The urban population of Kazakhstan (1917-1939) - Alma-Ata: Nauka, 1988. - 24 p. [In Rus.]

Radlov, 1989 - Radlov V.V. Iz Sibiri: stranitsy iz dnevnika. [From Siberia: diary pages]. M.: Nauka, 1989. 749 s. [In Rus.]

Sarkenova, 2011a - Sarkenova K.A. 1920-1930 zhyldardaġy Qazaqstan khalqy [The people of Kazakhstan in the 1920-1930s]. Almaty: Qazaq universitetí, 2011. 220 b. [In Kaz]

Sultangaliyeva, 2000a - Sultangaliyeva G. «Tatarskaya» diaspora v konfessional'nykh svyazyakh kazakhskoy stepi (XVIII-XIX vv.) [Tatarskaya diaspora in the confessional ties of the Kazakh steppe (XVIII-XIX centuries)] // Vestnik Yevrazii. 2000. №4. 20-37. [In Rus.]. 